\title{
Heavy Metals in Soils around the Cement Factory in Rockfort, Kingston, Jamaica
}

\author{
Arpita Mandal ${ }^{1}$, Mitko Voutchkov ${ }^{2}$ \\ ${ }^{1}$ Department of Geography and Geology, University of West Indies, Mona, Jamaica \\ ${ }^{2}$ Department of Physics, University of West Indies, Mona, Jamaica \\ E-mail: arpita_mandal2000@yahoo.com,mitko.voutchkov@uwimona.edu.jm \\ Received July 22, 2010; revised July 25, 2010; accepted July 28, 2010
}

\begin{abstract}
This study deals with the distribution of heavy metals in soils around one of the most important industries in Kingston, Jamaica i.e. the Carib Cement factory at Rockfort. The dust emitted from the Caribbean Cement Company Limited (Carib Cement), located in Rockfort, Kingston, gets deposited in course of time over the soil, leaves and forms a grey cover on the surrounding soils. Geochemical analysis of the top soil, collected from the present study area has been undertaken to assess the impact of the dust emitted from the cement factory and its effect on the surrounding ecosystem. A total of seventeen top soil samples of 0-10 cm depth were collected from the close vicinity of the Rockfort and the Harbour view area and analysed by INAA, AAS, XRF for major, minor and trace elements. Results show that the top soils of the study area are enriched in $\mathrm{Pb}, \mathrm{Zn}, \mathrm{Cr}, \mathrm{Cd}, \mathrm{V}, \mathrm{Pb}$, and $\mathrm{Hg}$ which are released into the air from the cement kilns. Results show that the soils are enriched in $\mathrm{Ca}$ with a maximum value of $18 \%$ followed by $\mathrm{Al}, \mathrm{Fe}$ and $\mathrm{Na}$. Heavy metals in the soils of the study area shows relatively high concentrations of zinc with a maximum of $132 \mathrm{ppm}$ followed by $\mathrm{Cr}$ (57) $\mathrm{ppm}$ and $\mathrm{Pb}$ (32) ppm. Maximum concentrations were found in soils sampled at a distance of 2-3 m from the cement factory as opposed to samples collected much further ie from the Harbour View area. High concentrations of the heavy metals in the soils near the cement factory as opposed to those further away can be due to the emissions from the factory. A significant contribution can also come from traffic emissions as the study area is located along one of the busiest street of Kingston, Jamaica.
\end{abstract}

Keywords: Cement, Dust, Rockfort, Kingston, Heavy Metals, Jamaica

\section{Introduction}

Heavy metals in urban soils are one of the main sources of environmental pollution. Metal contamination of surface soils [1], agricultural soils [2,3], from industries [4-6] and waste disposal sites [7] are well known. Heavy metals in the soil can also generate airborne particles and dust, especially in dry seasons, which affects the air quality $[8,9]$ Dust pollution has also been found to be problematic around cement factories [10,11]. In a study by Khashman and Shawabkeh 2006, soils around cement factories show high concentrations of heavy metals especially $\mathrm{Pb}, \mathrm{Zn}$ and $\mathrm{Cd}$ on top soils of $0-10 \mathrm{~cm}$ deep. Semhi et al. 2010 in their study on dust emitted from cement industries in Oman has shown high concentrations of REE and heavy metals in soils within a radius of 0.5 to 2 $\mathrm{km}$ around the cement factory. Their studies show dust affecting plants and the biota around the factories. Also the fine particulates of dust can be inhaled along with air and in course of time cause respiratory problems in people living near and working in the factory. Hence analysizing and characterization of the constituents of dust are very important from a health point of view. The Caribbean Cement Factory located at Rockfort, Kingston Jamaica is one of the largest industries generating $813,448 \mathrm{mt}$ of cement and is in the process of increasing its capacity to meet the growing demands of local and export markets. An islandwide study of trace and heavy metals in Jamaica by [12] shows maximum concentration of $\mathrm{Co}, \mathrm{Al}, \mathrm{Mn}, \mathrm{Cu}, \mathrm{Cd}, \mathrm{Zn}$ in the Central Parishes of Jamaica, correlating with the bauxite deposits of the island. Very less information is available on the distribution of metals around the Caribbean Cement factory at Rockfort. Hence the present study was undertaken to evaluate the 
environmental impact caused by emissions from the Rockort plant, located near an area where there are no other industries. Hence the excess concentrations of the heavy metals in the soils if found would be resulting from the dust emitted from the cement factory.

The area under investigation is located in Rockfort in the Parish of Kingston in Jamaica (Figure 1(a)). The area lies between $17^{\circ} 58^{\prime} 00 \mathrm{~N}, 76^{\circ} 44^{\prime} 10 \mathrm{~W}$ and $17^{\circ} 57^{\prime} 29$ $\mathrm{N}, 7^{\circ} 43^{\prime} 07 \mathrm{~W}$ covering a total of 5.6 square kilometers. The city of Kingston is located on an alluvial fan, fed with sediments from the Hope River which is the largest river in the Kingston hydrological Basin. The area has a complex geological history. It is bounded to the northeast by the Wagwater Group of conglomerates, sandstones, shales, to the immediate north by the limestone of the White Limestone Group, and to the west by alluvium. The Rockfort area lies below the White Limestones of the Long Mountain and is located on the Ligueanea alluvial fan. To the south of the cement factory is the Harbour view Community which is located on the Coastal Group of sediments (Figure 1(b)) . The soils of Jamaica can be classified into three broad categories namely highland soils eg. lithosols and clays derived from weathering of Cretaceous volcanics, upland plateau soils (terra rosa) overlying the limestone and the alluvial plain and valley soils covering most part of southern Jamaica. The present study area thus lies in the alluvial soil types of Jamaica.

\section{Methodology}

A total of seventeen top soil samples were collected from the study area, nine around the cement factory and another eight in the residential Harbour View community (Figure 1(c)). Bulk samples of $2 \mathrm{~kg}$ of top soil samples were collected within $0-10 \mathrm{~cm}$ depth. The soil samples were homogenized by coning and quartering, air-dried at $100-110^{\circ} \mathrm{C}$ for about $24 \mathrm{~h}$ and then finely powdered and sieved to $2 \mathrm{~mm}$ and further sieved to $150 \mu \mathrm{m}$ for analysis. Mineralogical analysis of the soil samples were carried out by X-Ray diffractometry in the Department of Chemistry at the University of West Indies. Elemental composition of the major, minor and trace elements in the soils were studied using a combination of X-Ray Fluorescence Spectrometry (XRF), Instrumental Neutron Activation Analysis (INAA) and Atomic Absorption Spectroscopy at the International Centre for Environmental and Nuclear Sciences (ICENS) at University of West Indies and Mines and Geology Division of the Ministry of Energy \& Mining, Jamaica. Pb was analyzed using KEVEX 770 energy dispersive X-Ray fluorescence (EDXRF) instrument. Al, Ca, K, Fe, Na, Zn, V and $\mathrm{Cr}$ were analysed by INAA using SLOWPOKE-2 nuclear reactor. The gamma-ray spectra were measured using Reverse Electrode Coaxial Ge Detectors (REGe)-CANBERRA interfaced to a 4096 channel Canberra Series 40 Multichannel Analyzer (MCA). Each sample was counted after the specified decay time at a counting geometry adjusted to give less than $10 \%$ dead time to minimize pulse pile-up. Spectrum analysis was carried out using the ORTEC Geligam software. All samples were irradiated in the SLOWPOKE 2 research reactor, the irradiation and measurement conditions are shown in the table below. A Canberra reverse electrode germanium detector with an efficiency of $15 \%$ at $1332.5 \mathrm{keV}$ gamma rays and a FWHM of $2.1 \mathrm{keV}$ was used for the counting of samples. Quantification was performed using the improved relative comparative method. Accuracy and precision of the INAA analytical procedures were evaluated by analyzing NIST-2711CRM in parallel with the samples. The overall agreement for the element analyzed was better than $10 \%$. The detection limits of the elements studied are included in Table 1.

For AAS the soil samples were weighed to $0.25 \mathrm{~g}$ in a weighing dish and transferred into a teflon beaker. Two milliliters of concentrated hydrochloric acid was carefully added then heated in a hot water bath at a temperature of about $90-95^{\circ} \mathrm{C}$ for 30 minutes. One milliliter of nitric acid long with $1 \mathrm{~mL}$ of perchloric acid and $2 \mathrm{~mL}$ of hydrofluoric acid were heated in the water bath until near dryness. The samples were redissolved with $3 \mathrm{~mL}$ concentrated hydrochloric acid and $1 \mathrm{~mL}$ concentrated nitric acid was heated in the water bath for 20 minutes which was then diluted to $10 \mathrm{~mL}$ with aluminium chloride then mixed and allowed to settle then the metals were measured by Perkin-Elmer FIMS-100 Flow Injection Mercury System (FIMS) and and Flame atomic absorption (PerkinElmer Analyst 300) respectively. The detection limits were $5 \mu \mathrm{g} / \mathrm{kg}$ for $\mathrm{Hg}$ and $1 \mathrm{mg} / \mathrm{kg}$ for $\mathrm{Cd}$.

\section{Results and Discussions}

Size analysis of the soil samples show that majority of the soils studied were in the range of 149-105 $\mu \mathrm{m}$ and < $53 \mu \mathrm{m}$ and are of fine sand to silt size range. Mineralogical analysis of the soil samples indicate presence of quartz, calcite, albite and potash feldspar as the most dominant minerals (Figure 2).

Chemical analysis of the top soils show that $\mathrm{CaO}$, $\mathrm{Al}_{2} \mathrm{O}_{3}$, and $\mathrm{K}_{2} \mathrm{O}$ are the major oxides followed by $\mathrm{Fe}_{2} \mathrm{O}_{3}$ and $\mathrm{NaO}$ (Table 1). This is also evident in the mineralogy of the soils where calcite, quartz and feldspars are the dominant minerals. The overall range of $\mathrm{Ca}$ in Jamaican soils is $<0.67 \%$ to $28.5 \%$ with most of the soils $<2 \%$. The average is $2.1 \%$ as compared with $1.4 \%$ of world soils [13]. The alluvial soils of Jamaica are reported 


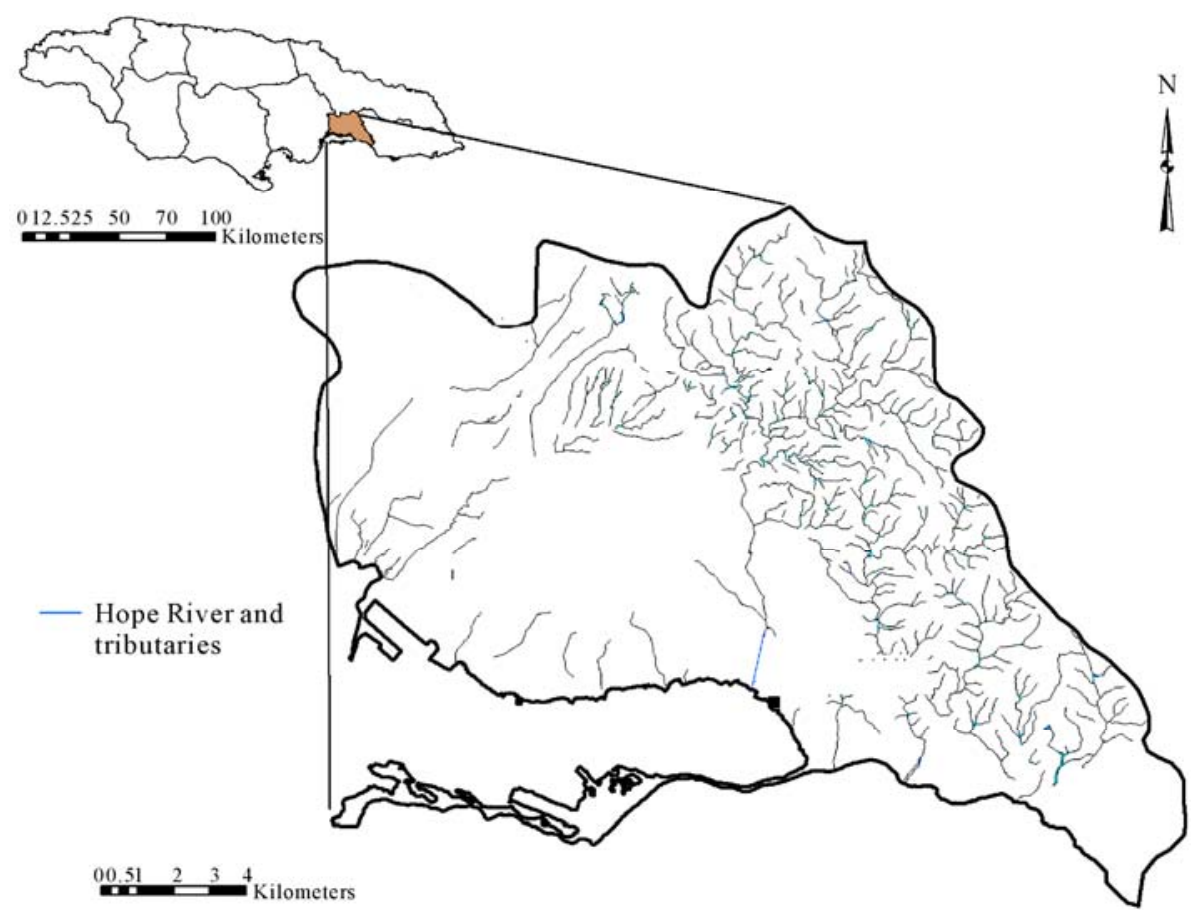

(a)

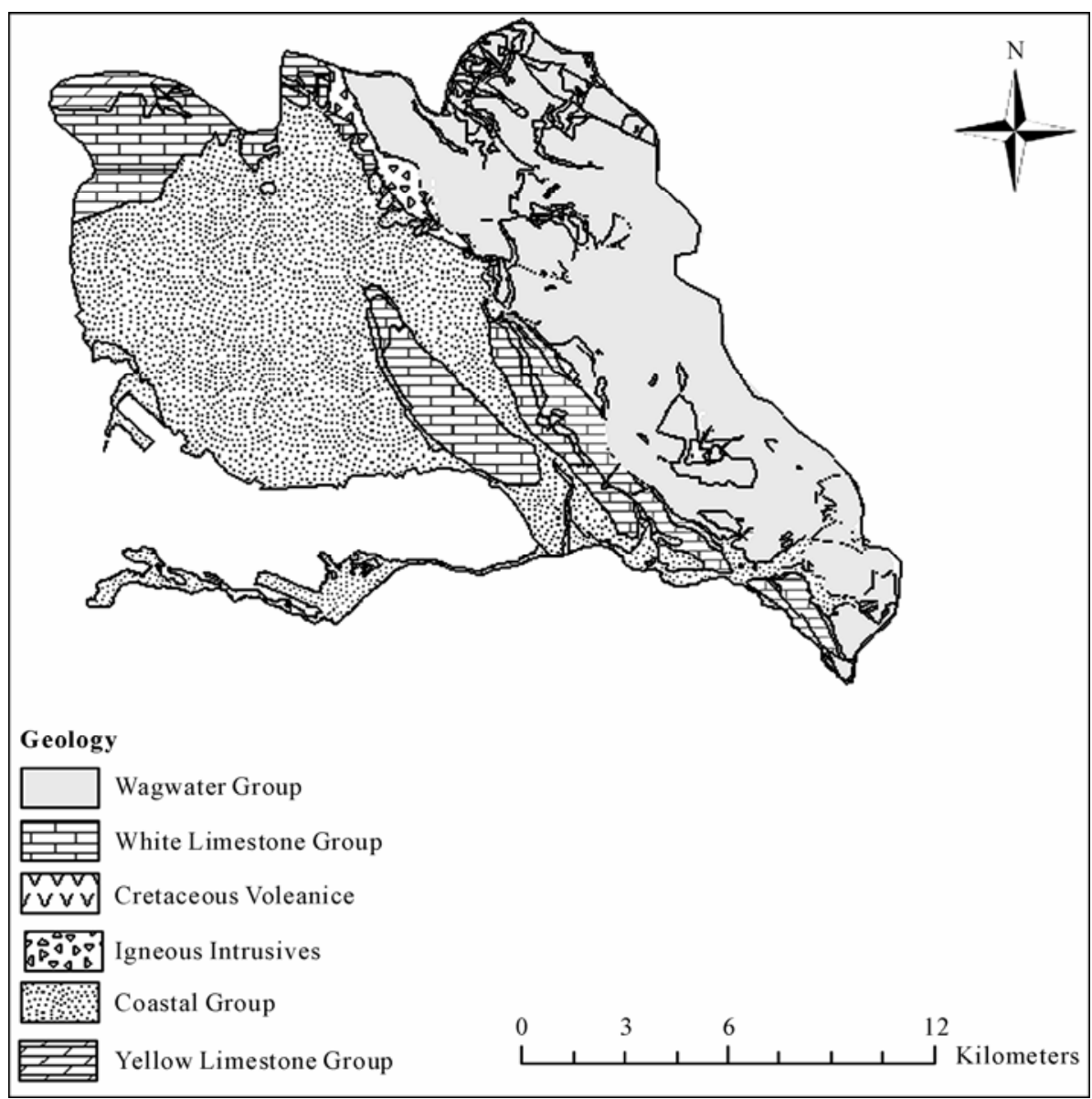

(b) 


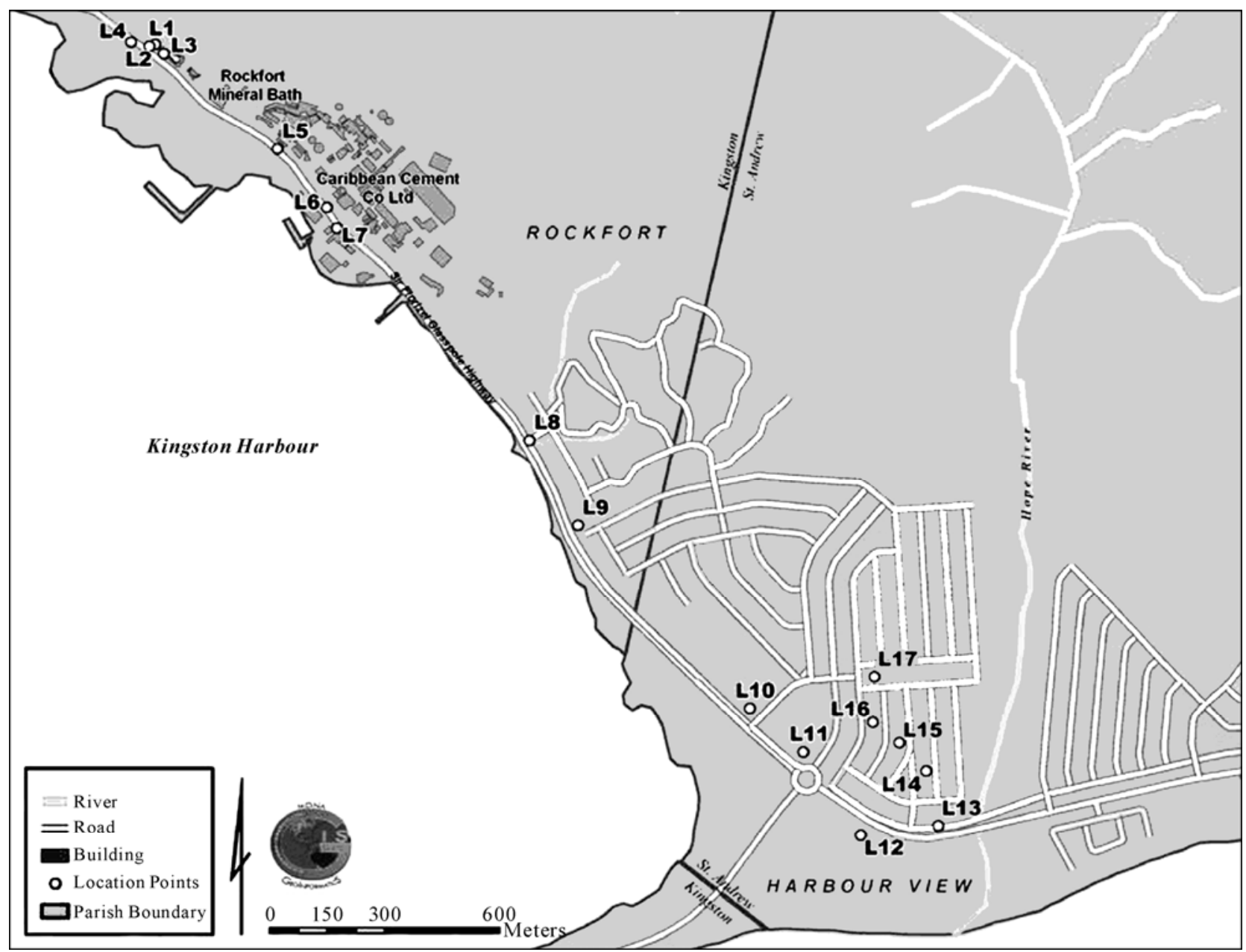

(c)

Figure 1. (a) Location map of Rockfort in Kingston, Jamaica; (b) Geological Map of Kingston-St Andrew, Jamaica; (c) Map of the Caribbean Cement Factory showing the sample locations (L1-L17).

to have low $\mathrm{Ca}$ values ranging from $<0.22 \%$ to $6.1 \%$, with the Ligueanea plains having releatively higher values (1.1-9.5\%). In the present study area $\mathrm{Ca}$ concentrations are higher in the soils bordering the factory (L4-L6, Table 1, Figure 1(c)) than those of the Harbour View area which could be attributed to its probable source from the dust emitted from the factory containing particulates of calcite, a dominant mineral of cement.

The trace element concentrations of the top soil samples show that the soils contain sufficient amounts of $\mathrm{Pb}$, $\mathrm{Zn}, \mathrm{Ti}, \mathrm{V}, \mathrm{Cd}$ and $\mathrm{Cr}$ (all results in ppm) (Table 2).

These metals originating from industrial activities are distributed in soils by the atmosphere within a distance that depends on the size of particles. The mean concentration of $\mathrm{Zn}$ and $\mathrm{Pb}$ in the soil samples are 132.03 and $31.47 \mathrm{ppm}$ respectively. Zinc and lead in soils could be derived from industrial sources as well as from abrasion from tyres of motor vehicles [14,15]. The highest concentrations of $\mathrm{Pb}$ and $\mathrm{Zn}$ were found in the samples near the gate of the plant, located at $5 \mathrm{~m}$ from the plant (Figure 1(c)) while the lowest concentrations of $\mathrm{Pb}$ and $\mathrm{Zn}$ (7.1 ppm and $67 \mathrm{ppm}$ ) were found further south in the Harbour View community. The $\mathrm{Pb}$ content of Jamaican soils have been found to enriched by a factor of 9 as compared to the crustal average of $13 \mathrm{ppm}$ in some areas [16]. Maximum concentrations are in soils overlying the White Limestone group of rocks. The soils of the study area fall within the Coastal Group and are reported to have $\mathrm{Pb}$ concentrations at some sites higher (75 ppm) than the average $\mathrm{Pb}$ in soils of Coastal Group (35 ppm).This could be attributed to the cement industry in which the process and production of cement industry require a substantial amount of energy supplied by burning fossil fuel and traffic activity in the plant $[17,18]$.The high levels of $\mathrm{Zn}$ in the top soils of the study area could be attributed to emission sources from the cement factory as well as traffic emissions in the area of investigation. Cadmium and Chromium also show a similar distribution 


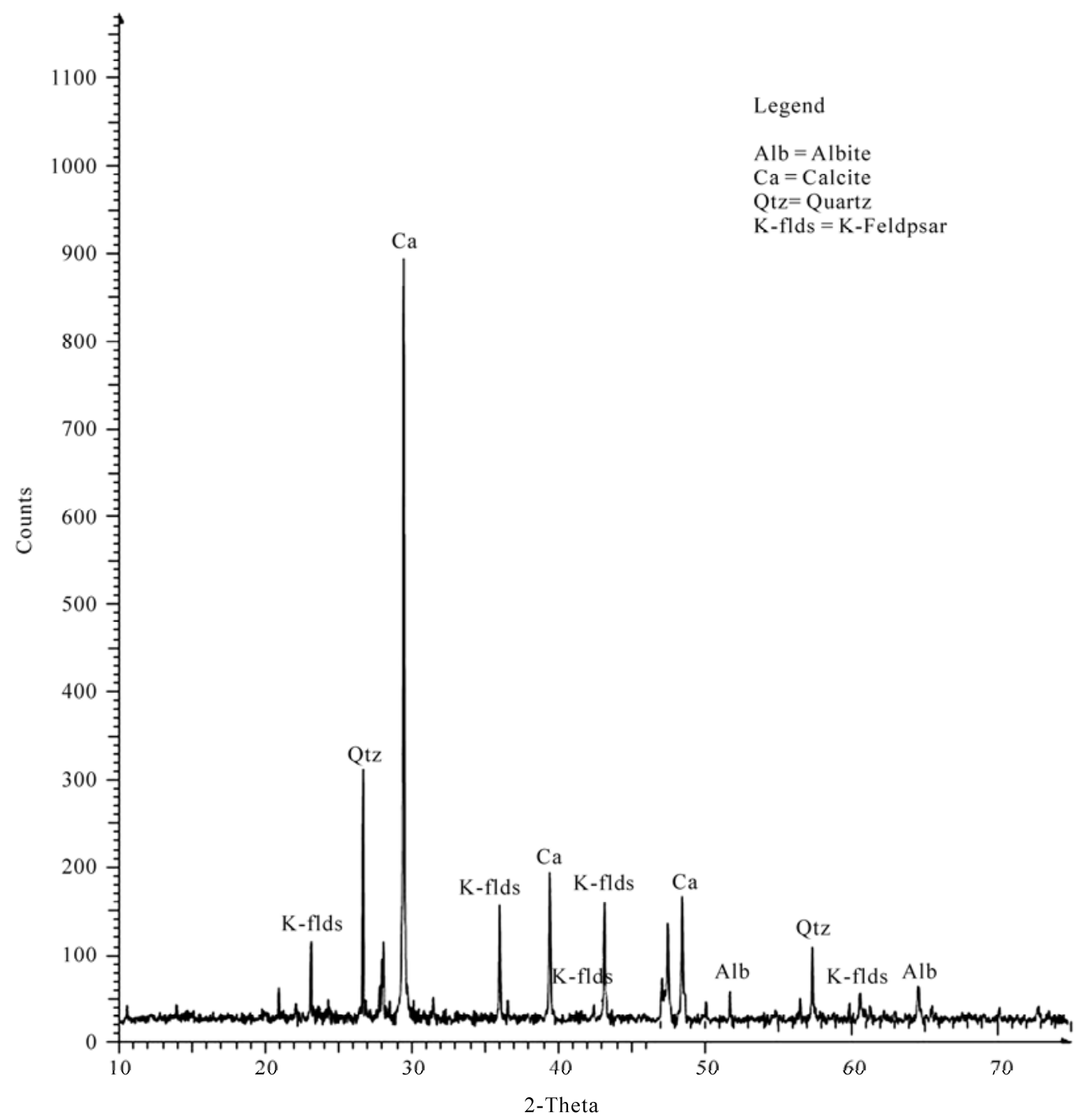

Figure 2. Representative X-Ray diffractogram of the top soil samples around the Caribbean Cement Factory, Rockfort, Jamaica.

pattern in the soils studied with relatively higher concentrations near the gate of the plant i.e. L4-L7 as opposed to soils sampled further south. Cd concentrations in alluvial soils are reported to be of an average of $1.5 \mathrm{ppm}$ According to Ellis and Revitt [18] Cd may be derived from the mechanical abrasion of vehicles and also associated with tyre wear. The concentration of chromium in the upper part of soil varies from 39.2-111.5 ppm with a mean value of $57.2 \mathrm{ppm}$. The highest concentrations of chromium are recorded in the samples near the plant and in the eastern area of the cement industry. In the cement industry the linings for the rotaries contain chromium, which could be liberated by wear and friction to be the source of chromium in the soil samples [17]. The Ti and $\mathrm{V}$ values fall within the range for Jamaican soils. In Jamaica Ti concentration $>0.6 \%$ have been reported from the bauxitic soils in the central and western Vanadium in the soils around cement factories can be attributed to the $\mathrm{V}$ in coal as coal is used during combustion processes in the cement factories.

Mutual correlations between the elements done at 95\% significance level shows positive correlation between $\mathrm{Pb}$ and $\mathrm{Zn}\left(\mathrm{R}^{2}=0.53\right)$ suggesting a possible common origin for them (Table 3 ). $\mathrm{V}$ and $\mathrm{Ti}$ show a very high positive correlation (0.91) between as compared to the other heavy metals. Hence it can be accounted for their similar source, probably coal as coal contains $\mathrm{Ti}$ and $\mathrm{V}$ in its trace element composition. Coal combustion releases these trace elements which can get incorportated in the dust along with the cement particulates and gets deposited on the top soil of the surrounding area.

$\mathrm{Cr}$ also shows good positive correlation with $\mathrm{Zn}\left(\mathrm{R}^{2}=\right.$ 
0.57) confirming further their common source (Table 3).

The present study shows that the metal concentrations of top soils can be used as a powerful geochemical tool for monitoring the impact of anthropogenic activity. Soil samples show higher concentrations of $\mathrm{Ca}$ as compared to the other major elements indicating the presence of calcareous soil in the area. Excess of $\mathrm{Ca}$ in the soils near the factory as opposed to the average levels of $\mathrm{Ca}$ in otherwise alluvial soils account for incorporation of cement particulates in the dust. Mutual correlation of the heavy metals in the soils suggests a common origin for $\mathrm{Pb}, \mathrm{Zn}$ and $\mathrm{Cr}$.

The distribution of the metal concentration of the soil in the study area indicated that this area has been affected by anthropogenic activity, in particular the cement

Table 1. Major elements (wt\%) in the top soil samples from the study area.

\begin{tabular}{|c|c|c|c|c|c|}
\hline ID & $\mathrm{Al} \%$ & $\mathrm{Ca} \%$ & $\mathrm{~K} \%$ & $\mathrm{Fe} \%$ & $\mathrm{Na} \%$ \\
\hline L1 & 3.8 & 18.8 & 2.1 & 0.8 & 0.9 \\
\hline L2 & 7.0 & 6.7 & 4.1 & 1.3 & 1.6 \\
\hline L3 & 6.1 & 9.2 & 3.4 & 1.3 & 1.1 \\
\hline L4 & 4.5 & 14.7 & 2.6 & 1.3 & 1.3 \\
\hline L5 & 5.3 & 12.3 & 3.7 & 1.2 & 1.7 \\
\hline L6 & 4.5 & 12.5 & 2.2 & 1.1 & 1.5 \\
\hline L7 & 6.2 & 6.6 & 3.5 & 1.5 & 1.7 \\
\hline L8 & 6.4 & 7.1 & 3.5 & 1.9 & 1.9 \\
\hline L9 & 5.9 & 8.8 & 3.1 & 1.5 & 2.2 \\
\hline L10 & 7.9 & 2.4 & 1.7 & 3.7 & 2.7 \\
\hline L11 & 5.6 & 10.3 & 1.9 & 4.2 & 2.0 \\
\hline L12 & 7.8 & 3.7 & 3.1 & 7.8 & 1.4 \\
\hline L13 & 6.9 & 8.0 & 1.8 & 4.4 & 0.9 \\
\hline L14 & 7.1 & 4.5 & 2.2 & 4.3 & 0.7 \\
\hline L15 & 4.6 & 15.5 & 2.8 & 2.9 & 2.4 \\
\hline L16 & 7.9 & 3.0 & 2.4 & 3.2 & 1.1 \\
\hline L17 & 7.5 & 6.1 & 2.2 & 4.1 & 1.6 \\
\hline Detection Limits & $0.022 \%$ & $0.184 \%$ & $1050 \mathrm{ppm}$ & $0.02 \mathrm{ppm}$ & $18 \mathrm{ppm}$ \\
\hline Max & 7.9 & 18.8 & 4.1 & 7.8 & 2.7 \\
\hline Min & 3.8 & 2.4 & 1.7 & 0.8 & 0.7 \\
\hline Mean & 6.2 & 8.8 & 2.7 & 2.7 & 1.6 \\
\hline Std Dev & 1.31 & 4.67 & 0.74 & 1.86 & 0.54 \\
\hline
\end{tabular}

Table 2. Mean, standard deviation and ranges for the metal concentration (ppm) for the soil samples collected from the study area along with their respective detection limits.

\begin{tabular}{|c|c|c|c|c|c|c|}
\hline ID & $\mathrm{Ti}$ & $\mathrm{Cd}$ & $\mathrm{Cr}$ & $\mathrm{Pb}$ & $\mathrm{Zn}$ & V \\
\hline L1 & 2838.0 & 6.18 & 40.5 & 21.5 & 78.5 & 87.4 \\
\hline L2 & 4497.2 & 7.44 & 50.9 & 16.0 & 103.8 & 136.4 \\
\hline L3 & 4727.7 & 6.48 & 44.3 & 18.3 & 95.0 & 125.0 \\
\hline L4 & 4618.3 & 5.42 & 78.2 & 44.0 & 259.8 & 118.7 \\
\hline L5 & 3353.5 & 4.33 & 111.5 & 28.3 & 165.7 & 120.9 \\
\hline L6 & 3029.2 & 5.06 & 48.3 & 61.9 & 146.1 & 92.0 \\
\hline L7 & 4434.3 & 7.84 & 54.4 & 57.0 & 249.8 & 125.0 \\
\hline L8 & 4303.3 & 3.46 & 39.3 & 42.0 & 139.0 & 153.9 \\
\hline L9 & 4650.6 & 2.51 & 82.1 & 27.4 & 152.4 & 102.1 \\
\hline L10 & 4851.8 & 5.7 & 56.9 & 18.7 & 115.5 & 137.3 \\
\hline L11 & 7045.1 & 7.1 & 46.4 & 50.9 & 156.3 & 192.1 \\
\hline L12 & 11362.0 & 6.1 & 51.6 & 75.6 & 103.5 & 368.6 \\
\hline L13 & 5613.7 & 4.5 & 72.4 & 33.0 & 130.0 & 169.0 \\
\hline L14 & 6376.5 & 3.4 & 51.4 & 7.1 & 125.0 & 149.1 \\
\hline L15 & 5288.0 & 5.2 & 52.7 & 10.0 & 74.7 & 151.5 \\
\hline L16 & 5383.7 & 3.9 & 45.3 & 7.6 & 67.5 & 133.0 \\
\hline L17 & 7445.2 & 4.5 & 46.3 & 15.7 & 82.0 & 150.0 \\
\hline Detection Limits & 1144 & 5.4 & 2.1 & 10 & 40.8 & 11.1 \\
\hline Max & 11362.00 & 7.84 & 111.54 & 75.64 & 259.78 & 368.63 \\
\hline Min & 2838.00 & 2.51 & 39.28 & 7.10 & 67.48 & 87.37 \\
\hline Mean & 147.77 & 5.24 & 57.21 & 31.47 & 132.03 & 138.54 \\
\hline Std Dev & 62.83 & 1.50 & 18.72 & 20.55 & 55.18 & 39.68 \\
\hline
\end{tabular}

Table 3. Correlation matrix between the metals in the soils from the study area.

\begin{tabular}{ccccccc}
\hline & $\mathrm{Ti}$ & $\mathrm{Cd}$ & $\mathrm{Cr}$ & $\mathrm{Pb}$ & $\mathrm{Zn}$ & $\mathrm{V}$ \\
\hline $\mathrm{Ti}$ & 1 & & & & & \\
$\mathrm{Cd}$ & 0.06 & 1.00 & & & & \\
$\mathrm{Cr}$ & -0.33 & 0.03 & 1.00 & & & \\
$\mathrm{~Pb}$ & 0.29 & 0.31 & 0.29 & 1.00 & & \\
$\mathrm{Zn}$ & -0.21 & 0.17 & 0.57 & 0.53 & 1.00 & \\
$\mathrm{~V}$ & 0.91 & 0.16 & -0.20 & 0.47 & -0.16 & 1 \\
\hline
\end{tabular}


industry, leading to a high accumulation of heavy metals in the soils located near the factory as compared with the soils further to the south east of the factory. The distribution of the metal concentration of the soil in study area indicated that the cement industry together with the traffic emissions were mainly responsible for metal pollution in this area. Further study is needed not only to assess the distribution of metals in soil but also to examine variation on small scale. More intensive sampling is necessary to show any change or increase of metals in the investigated area over time.

\section{Acknowledgements}

The authors greatly acknowledge the assistance offered by the International Center for Nuclear Science, UWI, Mona, Chemistry Department at UWI Mona, Mona Geoinformatix Ltd, Mines and Geology Division, Ministry of Energy, Mining \& Telecommunication, in sample analysis and production of population density map of Kingston.

\section{References}

[1] J. Pichtel, J, H. T. Sawyerr and Czarnowska, K, "Spatial and Temporal Distribution of Metals in Soils in Warsaw, Poland," Environmental Pollution, Vol. 98, No. 2, 1998, pp. 169-174. doi:10.1016/S0269-7491(97)00131-0

[2] K. Kim and S. Kim, "Heavy Metal Pollution of Agricultural Soils in Central Regions of Korea," Water Air and Soil Pollution, Vol. 82, 1998, pp. 109-122. doi: $10.1007 / \mathrm{s} 002540050484$

[3] V. K. Sharma, K. B. Rhudy, J. C. Cargill, M. E. Tacker and F. G. Vazquez, "Metals and Grain Size Distributions in Soil of the Middle Rio Grande Basin, Texas, USA," Environmental Geology, Vol. 39, No. 2, 2000, pp. 698-704.

[4] S. M. Ullrich, M. H. Ramsey and E. Helios-Rybicka, "Total and Exchangeable Concentrations of Heavy Metals in Soils Near Bytom, an Area of $\mathrm{Pb} / \mathrm{Zn}$ Mining and Smelting in Upper Silesia, Poland," Applied Geochemistry, Vol. 14, 1999, pp.87-196. doi:10.1016/S0883-2927(98)00042-0

[5] L. Bityukova, A. Shogenova and M. Brike, "Urban Geochemistry: A Study of Element Distributions in the Soils of Tallinn (Estonia)," Environmental Geochemistry and Health, Vol. 22, 2000, pp.172-193. doi:10.1023/A:1006754326260

[6] T. Sterckeman, F. Douay, N. Proix and H. Fourrier, "Vertical Distribution of $\mathrm{Cd}, \mathrm{Pb}$ and $\mathrm{Zn}$ in Soils near Smelters in the North of France," Environmental Pollution, Vol. 107, 2000, pp. 377-389. doi:10.1016/S0269-7491(99)00165-7

[7] P. S. Yarlagadda, M. R. Matsumoto, J. E. VanBenschoten,
A. Kathuria, "Characteristics of heavy metals in contaminated soils," Journal of Environmental Engineering, Vol. 121, No. 4, 1995, pp. 276-286. doi:10.1061/(ASCE)0733-9372(1995)121:4(276)

[8] T. B. Chen, W. J. C. Wong, H. Y. Zhou and M. H. Wong, "Assessment of Trace Metal Distribution and Contamination in Surface Soil of Hong Kong," Environmental Pollution, Vol. 96, 1997, pp. 61-68. doi:10.1016/S0269-7491(97)00003-1

[9] C. W. Gray, R. G. McLaren and A. H. C. Roberts, "Atmospheric Accessions of Heavy Metals to Some New Zealand Pastoral Soils," The Science of the Total Environment, Vol. 305, 2003, pp. 105-115. doi:10.1016/S0048-9697(02)00404-7

[10] K. Semhi, S. A. Khirbash, O. Abdalla, T. Khan, J. Dupley, S. Chaudhuri and S. A. Saidi, "Dry Atmospheric Contribution to the Plant-Soil System around a Cement Factory: Spatial Variations and Sources-A Case Study from Oman," Water Air and Soil Pollution, Vol. 205, 2010, pp. 343-357. doi:10.1007/s11270-009-0079-8

[11] O. A. Khashman and R. A. Shawabkeh, "Metal Distribution in Soils around the Cement Factory in Southern Jordan," Environmental Pollution, Vol. 140, 2006, pp. 387-394. doi:10.1016/i.envpol.2005.08.023

[12] H. Robotham, G. C. Lalor, A. Mattis and Rof. Rattray, "Trace Elements in Jamaican Soils," Journal Radio Analytical and Nuclear Chemistry, Vol. 116, No. 1, 2003, pp. 27-34. doi:10.1007/BF02037208

[13] G. C. Lalor, et al., "A Geochemical Atlas of Jamaica," Canoe Press, UWI, Kingston, Jamaica, 1995.

[14] J. Garty, M. Kauppi and A. Kauppi, "Accumulation of Airborne Elements from Vehicles in Transplanted Lichens in Urban Sites," Journal of Environmental Quality, Vol. 25, 1996, pp. 265-272. doi:10.2134/jeq1996.00472425002500020009x

[15] H. A. Carreras and M. L. Pignata, "Biomonitoring of Heavy Metals and Air Quality in Cordoba City, Argentina, Using Transplanted Lichens," Environmental Pollution, Vol. 17, 2002, pp. 77-87. doi:10.1016/S0269-7491(01)00164-6

[16] A. Johnson, G. C. Lalor, J. Preston and M. Voutchkov, "Heavy Metal Pollution in Jamaica 2: Background Levels of Lead in Jamaican Soils," Jamaican Jour of Science and Technology, Vol. 7 \& 8, 1996, pp. 1-12.

[17] K. M. Banat, F. M. Howari and A. A. Al-Hamad, "Heavy Metals in Urban Soils of Central Jordan: Should We Worry about Their Environmental Risks," Environmental Research, Vol. 97, 2005, pp. 258-273. doi:10.1016/j.envres.2004.07.002

[18] J. B. Ellis and D. M. Revitt, "Incidence of Heavy Metals in Street Surface Sediments: Solubility and Grain Size Studies," Water, Air and Soil Pollution, Vol. 17, 1982, pp. 87-100. 